\title{
Complete response to ipilimumab and nivolumab therapy in a patient with extensive extrapulmonary high-grade small cell carcinoma of the pancreas and HIV infection
}

\author{
Muhammad Husnain ${ }^{1}$, Wungki Park', Juan Carlos Ramos', Thomas E. Johnson², Joseph Chan ${ }^{3}$, Arvind Dasari ${ }^{4}$,
} Raja Mudad ${ }^{1}$ and Peter J. Hosein ${ }^{1 *}$ (D)

\begin{abstract}
Background: Immune checkpoint inhibitors (CPIs) have shown promising results in many solid tumors. There are limited data on the safety and efficacy of these drugs in HIV infected patients as they have traditionally been excluded from CPIs clinical trials.

Case presentation: We present a case of an HIV-positive patient with extensive extrapulmonary high-grade small cell carcinoma who was treated with dual CPIs (nivolumab and ipilimumab) with a complete response to therapy and with a manageable safety profile. We performed a comprehensive literature review identifying 62 total HIV positive cases treated with CPIs showing this to be a potentially safe option in HIV-positive patients.
\end{abstract}

Conclusion: HIV infection is not an absolute contraindication to CPI therapy. Our case and others provide justification for ongoing trials of CPI therapy in patients with HIV infection, a group that has traditionally been excluded from clinical trials.

Keywords: Check point inhibitors, Immunotherapy, HIV, Small cell cancer, Neuroendocrine carcinoma

\section{Background}

Immune checkpoint inhibitors (CPIs) including anti-programmed cell death 1 (PD-1), anti-PD ligand 1 (PD-L1) and anti-cytotoxic lymphocyte associated protein 4 (CTLA-4) antibodies have shown promising results in several solid cancers including small cell lung cancers. Small cell lung cancer (SCLC) is a poorly differentiated high-grade neuroendocrine carcinoma representing $15 \%$ of all lung cancers with very poor prognosis [1]. CheckMate-032 and KEYNOTE-028 showed modest activity of CPIs in recurrent SCLC patients and high-grade pancreatic neuroendocrine carcinomas [2, 3].

\footnotetext{
* Correspondence: phosein@med.miami.edu

1Department of Medicine, Division of Oncology, University of Miami Miller School of Medicine and Sylvester Comprehensive Cancer Center, 1475 NW 12th Ave. Suite 3400, Miami, FL 33136, USA

Full list of author information is available at the end of the article
}

CheckMate-032 was a phase I/II trial of nivolumab (anti-PD-1 antibody) alone or nivolumab plus ipilimumab (anti-CTLA-4 antibody) in recurrent SCLC patients showing acceptable toxicity and clinically meaningful responses with 1-year overall survival rate of 27 and $48 \%$ for nivolumab alone and nivolumab plus ipilimumab arms respectively. KEYNOTE-028 studied the role of pembrolizumab (Anti-PDL1 antibody) in pancreatic neuroendocrine tumors and carcinoid tumors showing stable disease in 88 and $69 \%$ of patients respectively with a median follow up of 20 months. All the CPI trials excluded patients with chronic infections including HIV. There is limited data on the safety of CPI in HIV positive patients. We present a case of an extrapulmonary small cell cancer of pancreas in an HIV-positive patient who had a complete response to dual CPI therapy. We also review all the

(c) The Author(s). 2018 Open Access This article is distributed under the terms of the Creative Commons Attribution 4.0 International License (http://creativecommons.org/licenses/by/4.0/), which permits unrestricted use, distribution, and 
evidence available to date on the safety of check point inhibitors in HIV-positive patients.

\section{Case presentation}

A 52-year-old man was first diagnosed with HIV in 1991. He was maintained on antiretroviral therapy with emtricitabine-tenofovir and raltegravir. The HIV viral load was undetectable (less than 20 copies $/ \mathrm{ml}$ ) and the CD4 count of 850 cells/uL at the time of presentation. In December 2016, he presented to the emergency department with chief complaint of diplopia. A magnetic resonance imaging (MRI) of the orbits revealed a mass in the left orbit with involvement of the optic nerve. He was referred to ophthalmology and underwent a lateral orbitotomy and removal of the orbital mass. Pathology showed metastatic small cell carcinoma. A Computed Tomography (CT) scan of the chest, abdomen and pelvis and a Positron Emission Tomography (PET) scans were negative for any intrathoracic mass; however, there were multiple liver lesions and a large pancreatic tail mass. Given these findings his final diagnosis was extrapulmonary high-grade small cell carcinoma of the pancreas. Next Generation Sequencing of his tumor showed an intermediate tumor mutation burden with 9 mutations/ megabases and deleterious alterations in TP53, MLL3, MEN1, FAT1, CDKN2A, BCORL1, BCOR, ATRX and TSC2 genes. There is currently no approved targeted therapy for any of these mutations. He was started on chemotherapy with carboplatin and etoposide. He had a partial response (PR) after 2 cycles of chemotherapy. He had disease progression after 6 cycles of chemotherapy with carboplatin and etoposide. He was then started on chemotherapy with FOLFIRINOX (5-Fluorouracil, irinotecan, leucovorin and oxaliplatin) as second line therapy. He received four cycles but continued to have disease progression on imaging. He was then treated with carboplatin and paclitaxel but his disease continued to progress with clinical deterioration and significant abdominal pain. At that point, treatment with dual CPI therapy (nivolumab and ipilimumab) was pursued given the available data in refractory SCLC. Before the start of this therapy, his CD 4 count was 294 cells/uL with an undetectable HIV viral load (less than 20 copies $/ \mathrm{ml}$ ). He received Nivolumab $1 \mathrm{mg} / \mathrm{Kg}$ along with Ipilimumab $3 \mathrm{mg} / \mathrm{kg}$ every 3 weeks. After 2 doses of the combination, he developed acute kidney injury with creatinine of $4.2 \mathrm{mg} / \mathrm{dl}$ from a baseline of 1.0. The therapy was suspended and he was admitted to the hospital and a renal biopsy was performed which showed severe drug-induced acute interstitial nephritis (AIN). He was treated with high dose steroids; $500 \mathrm{mg}$ of IV methylprednisolone for 3 days followed by a steroid taper. His renal function improved after 4 weeks with return of creatinine to baseline. He was then re-started on single agent Nivolumab at $1 \mathrm{mg} / \mathrm{Kg}$ and later ipilimumab at $1 \mathrm{mg} / \mathrm{kg}$ was added. The patient had significant clinical improvement soon after starting the dual CPI therapy with resolution of abdominal pain which previously required high-dose opioids. Repeat scans at 12 weeks (including MRI of the head and PET/CT scan) showed complete response (CR) as per PERCIST criteria with disappearance of all metabolically active lesions (Fig. 1). Patient was continued on antiretroviral therapy. The HIV viral load was undetectable before starting the CPIs $(<20$ copies $/ \mathrm{ml}$ ) and increased to a high of 175 copies $/ \mathrm{ml}$. At the same time his absolute CD4 count increased from 294 cells/uL before treatment to a high of 593 cells/uL. His CD8 count also followed the similar pattern. It was 111 cell/uL before starting treatment and reached a high of 247 cells/uL (Fig. 2). The patient's complete radiological response is still ongoing at the time of this report (24 weeks after the start of the dual CPI therapy).

\section{Discussion and conclusions}

Many cases of exceptional and durable responses to CPIs have been reported. However, this case is unique in that it highlights the impressive efficacy of dual CPIs in a HIV positive patient. The only drug-related adverse effect was acute interstitial nephritis (AIN), successfully treated with high dose steroids. The patient achieved a complete clinical and PET response. Patient continued on antiviral therapy during the entire course of therapy. There was no significant adverse effect on the HIV viral load and CD4 cell counts. Interestingly, his viral load which was undetectable before the start of the CPI therapy increased to 106 copies $/ \mathrm{ml}$ at week 10 followed by a drop in HIV viral load to 80 copies/ml at week 12 . At the same time his CD4+ cell count increased to 593 cells/Ul at week 10 and dropping down to 507 cells/Ul at week12. Day et al. have shown that in untreated HIV infection PD-1 was significantly upregulated on HIV specific CD4 and CD8 $\mathrm{T}$ cells leading to $\mathrm{T}$ cell exhaustion and PD-1 blockade resulted in proliferation of HIV specific CD4 and CD 8 T cells and decrease in viral load $[4,5]$. Guihot et al. treated an HIV positive patient with lung cancer with nivolumab showing a transient reactivation of HIV replication within CD4 $\mathrm{T}$ cells together with HIV specific CD8 T-cell activation that might be responsible for killing these reactivated HIV-producing cells resulting in an elimination of HIV reservoir and potential cure of HIV [6]. Smari et al. reported similar findings in an HIV positive patient with non-small cell lung cancer (NSCLC) who was treated with nivolumab and they concluded that nivolumab is successful at enhancing the HIV-specific CD8 $\mathrm{T}$ cells to proliferate and secrete cytokines, with promising results on the decrease of the HIV reservoirs [7]. In fact, a clinical trial of anti-PD-L1 antibody BMS-936559 in HIV positive patients is underway to determine the safety and efficacy 


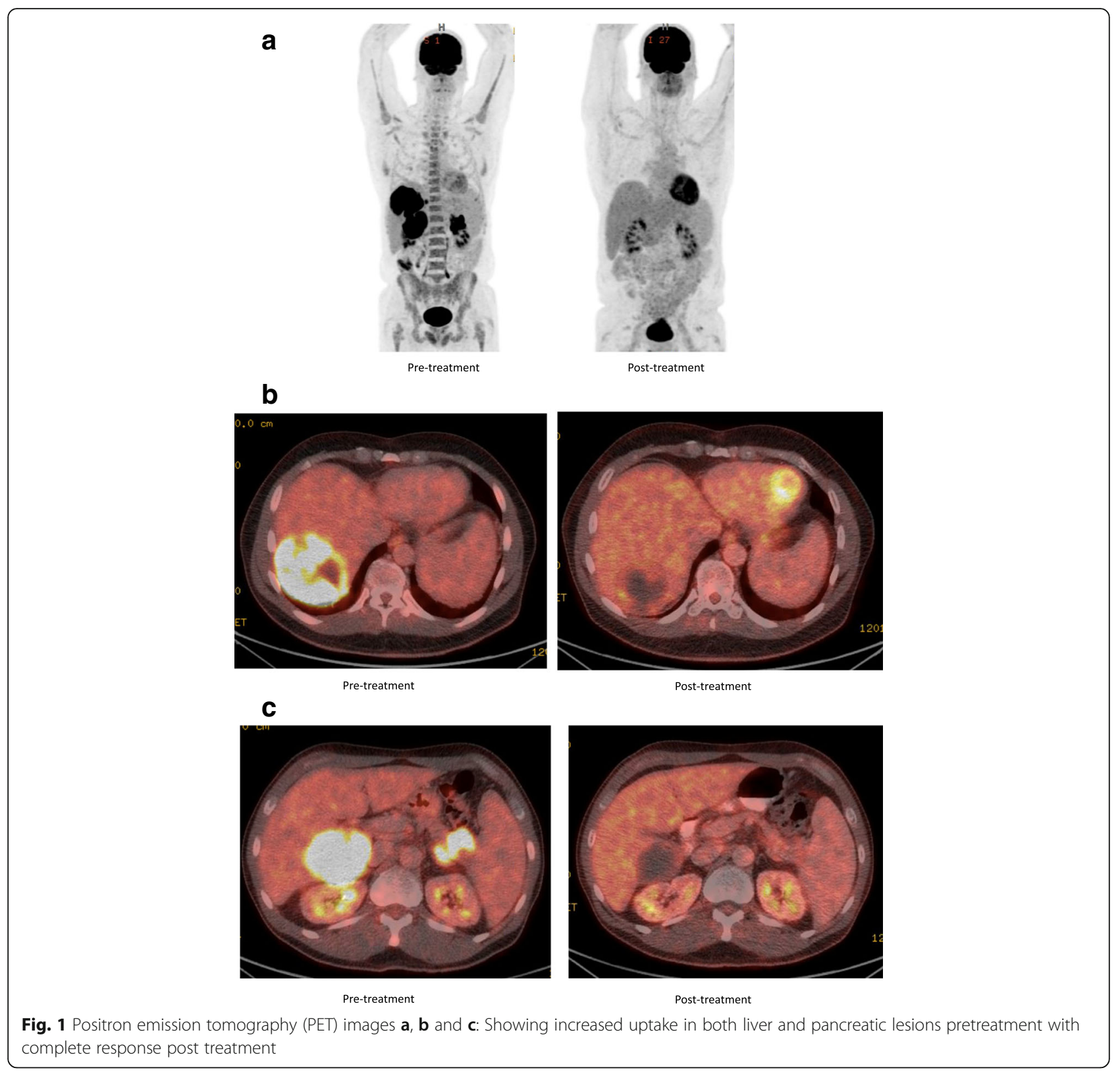

of CPIs in HIV-positive patients as a therapeutic option to suppress HIV viral loads [8].

We performed a comprehensive literature review for use of CPIs in HIV positive patients. Search terms "immunotherapy", "PD-1", "CTLA-4", "PD-L1", “Checkpoint inhibitors", "nivolumab", “ipilimumab”, "pembrolizumab", "HIV", "AIDS" were used to search PubMed, congress abstracts from the annual meetings of the American Society of Clinical Oncology, European Cancer Congress, Society of Immunotherapy of cancer, American Association of Cancer Research and Google Scholar and for ongoing trials in ClinicalTrials.gov.

Our search identified 12 case reports [6,9-18], 3 retrospective case series $[7,19,20]$ and 1 prospective phase 1 clinical trial (NCT02595866) for HIV positive patients being treated with checkpoint inhibitors (Table 1). Uldrick et al. (NCT02595866) presented the interim analysis from Cancer Immunotherapy Trials Network-12 (CITN-12): A phase 1 study of pembrolizumab in patients with HIV and relapsed, refractory or disseminated malignancies. Seventeen HIV- positive patients with various malignancies were treated with pembrolizumab $200 \mathrm{mg}$ intravenously every 3 weeks without any significant adverse effects on CD4+ cell count and HIV viral load. Rai et al.... reported a series of 44 patients with malignant tumors and concurrent solid organ transplant, $\mathrm{HIV}, \mathrm{HBV}$ or $\mathrm{HCV}$ infection treated with CPIs. Among these, 11 were HIV-positive and there 


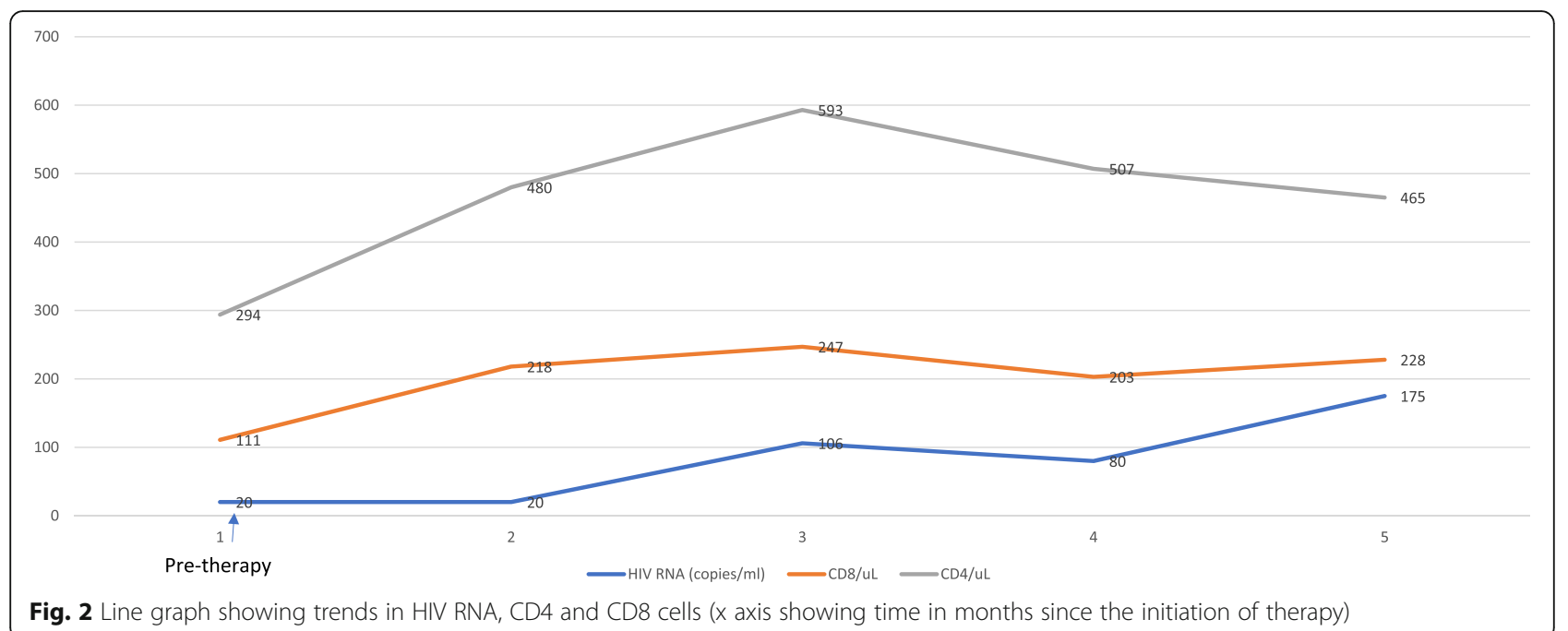

were no adverse effects on their HIV viral load and CD $4+$ cell counts [20]. Similarly, Heppt et al and Samri et al treated 10 and 12 HIV positive patients respectively with CPIs showing similar results [7, 19]. Several other phase I/II clinical trials (NCT02408861 and NCT03304093) are underway to test the safety and efficacy of CPIs either alone or in combination in patients with HIV and advanced solid tumors.

In summary, it appears that HIV infection is not an absolute contraindication to CPI therapy. Although the safety is not fully defined, we present a patient who had an exceptional response to therapy with a manageable safety profile. Apart from the therapeutic effect against the malignancy, there are emerging data that the HIV disease itself may be favorably affected by CPI therapy and studies for this indication are also ongoing. Our case and others provide justification for ongoing trials of CPI therapy in patients with HIV infection, a group that has traditionally been excluded from clinical trials.

Table 1 Safety and efficacy of HIV positive patients treated with immune checkpoint inhibitors

\begin{tabular}{|c|c|c|c|c|}
\hline Study & $\begin{array}{l}\text { No of patients } \\
\text { with HIV }\end{array}$ & Disease & Viral response & Disease response \\
\hline Rai et al. 2017 [20] & 11 & $\begin{array}{l}8 \text { Melanoma, } 1 \text { HCC, } 1 \text { RCC, } \\
1 \text { BC }\end{array}$ & $\begin{array}{l}\text { No pt. had loss in viral control or immune } \\
\text { reconstitution inflammatory syndrome }\end{array}$ & $\begin{array}{l}2 \mathrm{CR}, 1 \mathrm{PR}, 4 \mathrm{SD}, \\
4 \mathrm{PD}\end{array}$ \\
\hline Heppt et al. 2017 [19] & 10 & Melanoma & No increase in viral load, no effect on CD4 count & \\
\hline Wightman et al. 2015 [18] & 1 & Melanoma & Improved CD4 count and decrease in Viral load & NA \\
\hline Burke et al. 2011 [9] & 1 & Melanoma & Stable CD 4 count and viral load & PR \\
\hline Morris et al. 2017 [14] & 2 & Anal cancer & Stable CD4 count and viral load & NA \\
\hline Sandoval-Sus et al. 2017 [16] & 1 & Hodgkin lymphoma & Stable CD4 count and viral load & PR \\
\hline Tomsitz et al. 2017 [17] & 1 & Melanoma & Stable CD4 count and viral load & PR \\
\hline Ruzevick et al. 2013 [15] & 1 & Melanoma & Stable CD4 count and viral load & PR \\
\hline Davar et al. 2015 [10] & 1 & Melanoma & Stable CD4 count and viral load & PD \\
\hline Le Garff et al. 2017 [12] & 1 & NSCLC & CD4 count increased with stable viral load & PD \\
\hline Guihot et al. 2017 [6] & 1 & NSCLC & Stable CD4 count and viral load & PR \\
\hline Samri et al. 2017 [7] & 12 & NSCLC & Stable CD4 count and viral load & $3 \mathrm{PR}, 4 \mathrm{SD}, 5 \mathrm{PD}$ \\
\hline Hentrich et al. 2017 [11] & 1 & NSCLC & $\begin{array}{l}\text { CD4 count decreased but viral load remained } \\
\text { stable }\end{array}$ & PD \\
\hline McCullar et al. 2017 [13] & 1 & NSCLC & $\begin{array}{l}\text { CD4 count decreased but viral load remained } \\
\text { stable }\end{array}$ & $C R$ \\
\hline $\begin{array}{l}\text { Uldrick et al. } 2017 \\
\text { (NCT02595866) }\end{array}$ & 17 & Mix & $\begin{array}{l}\text { Increase in CD4 count, viral load remained } \\
\text { suppressed }\end{array}$ & NA \\
\hline
\end{tabular}




\section{Authors' contributions}

$\mathrm{MH}$, WP and PH involved in concept, design and drafting the manuscript. JR, $T J, J C, A D, R M$ and PH approved the final draft and gave their intellectual input.

\section{Ethics approval and consent to participate}

Not applicable

\section{Consent for publication}

Yes

\section{Competing interests}

The authors declare that they have no competing interests.

\section{Publisher's Note}

Springer Nature remains neutral with regard to jurisdictional claims in published maps and institutional affiliations.

\section{Author details}

'Department of Medicine, Division of Oncology, University of Miami Miller School of Medicine and Sylvester Comprehensive Cancer Center, 1475 NW 12th Ave. Suite 3400, Miami, FL 33136, USA. ${ }^{2}$ Department of Ophthalmology, University of Miami Miller School of Medicine and Bascom Palmer Eye Institute, Miami, USA. ${ }^{3}$ Department of Medicine, Division of Infectious Diseases, University of Miami Miller School of Medicine, Mount Sinai Medical Center, Miami, USA. ${ }^{4}$ MD Anderson Cancer Center, Houston, USA.

Received: 26 March 2018 Accepted: 20 June 2018

Published online: 09 July 2018

\section{References}

1. Gazdar AF, Bunn PA, Minna JD. Small-cell lung cancer: what we know, what we need to know and the path forward. Nat Rev Cancer. 2017:17:725-37.

2. Antonia SJ, López-Martin JA, Bendell J, Ott PA, Taylor M, Eder JP, Jäger $D$, Pietanza MC, Le DT, de Braud F, et al. Nivolumab alone and nivolumab plus ipilimumab in recurrent small-cell lung cancer (CheckMate 032): a multicentre, open-label, phase 1/2 trial. The Lancet Oncology. 17:883-95.

3. Mehnert J, Rugo H, O'neil B, Santoro A, Schellens J, Cohen R, Doi T, Ott P, Pishvaian M, Puzanov I. Pembrolizumab for patients with PD-L1-positive advanced carcinoid or pancreatic neuroendocrine tumors: results from the Keynote-028 study. Ann Oncol. 2017;28 (suppl_5): v142-v157.

4. Day CL, Kaufmann DE, Kiepiela P, Brown JA, Moodley ES, Reddy S, Mackey EW, Miller JD, Leslie AJ, DePierres C, et al. PD-1 expression on HIV-specific T cells is associated with T-cell exhaustion and disease progression. Nature. 2006;443:350-4.

5. Rao M, Valentini D, Dodoo E, Zumla A, Maeurer M. Anti-PD-1/PD-L1 therapy for infectious diseases: learning from the cancer paradigm. Int J Infect Dis. 2017;56:221-8.

6. Guihot A, Marcelin AG, Massiani MA, Samri A, Soulié C, Autran B, Spano JP. Drastic decrease of the HIV reservoir in a patient treated with nivolumab for lung cancer. Ann Oncol 2018;29(2):517-518.

7. Samri A, Lavolé A, Even S, Lambert-Niclot S, Le Garff G, Cadranel J. Immunovirological evolution in HIV-infected patients treated with anti-PD-1 therapy. In International Aids Society Conference. 2017;

8. Gay CL, Bosch RJ, Ritz J, Hataye JM, Aga E, Tressler RL, Mason SW, Hwang CK, Grasela DM, Ray N, et al. Clinical trial of the anti-PD-L1 antibody BMS936559 in HIV-1 infected participants on suppressive antiretroviral therapy. J Infect Dis. 2017;215:1725-33.

9. Burke MM, Kluger HM, Golden M, Heller KN, Hoos A, Sznol M. Case report: response to ipilimumab in a patient with HIV with metastatic melanoma. J Clin Oncol. 2011;29:e792-4.

10. Davar D, Wilson M, Pruckner C, Kirkwood JM. PD-1 blockade in advanced melanoma in patients with hepatitis C and/or HIV. Case Rep Oncol Med. 2015;2015:737389

11. Hentrich M, Schipek-Voigt K, Jager H, Schulz S, Schmid P, Stotzer O, Bojko P. Nivolumab in HIV-related non-small-cell lung cancer. Ann Oncol. 2017; 28(11):2890

12. Le Garff G, Samri A, Lambert-Niclot S, Even S, Lavole A, Cadranel J, Spano JP, Autran B, Marcelin AG, Guihot A. Transient HIV-specific T cells increase and inflammation in an HIV-infected patient treated with nivolumab. Aids. 2017;31:1048-51.
13. McCullar B, Alloway T, Martin M. Durable complete response to nivolumab in a patient with HIV and metastatic non-small cell lung cancer. J Thorac Dis. 2017;9:E540-e542.

14. Morris VK, Salem ME, Nimeiri H, lqbal S, Singh P, Ciombor K, Polite B, Deming $D$, Chan E, Wade JL, et al. Nivolumab for previously treated unresectable metastatic anal cancer (NC19673): a multicentre, single-arm, phase 2 study. Lancet Oncol. 2017;18:446-53.

15. Ruzevick J, Nicholas S, Redmond K, Kleinberg L, Lipson EJ, Lim M. A patient with HIV treated with Ipilimumab and stereotactic radiosurgery for melanoma metastases to the brain. Case Rep Oncol Med. 2013;2013:946392.

16. Sandoval-Sus JD, Mogollon-Duffo F, Patel A, Visweshwar N, Laber DA, Kim R, Jagal MV. Nivolumab as salvage treatment in a patient with HIV-related relapsed/refractory Hodgkin lymphoma and liver failure with encephalopathy. J Immunother Cancer. 2017;5:49.

17. Tomsitz D, Hein R, Biedermann T, Kohlmeyer J. Treatment of a patient with HIV and metastatic melanoma with consequitive ipilimumab and nivolumab. J Eur Acad Dermatol Venereol. 2018;32(1):e26-e28.

18. Wightman F, Solomon A, Kumar SS, Urriola N, Gallagher K, Hiener B, Palmer S, McNeil C, Garsia R, Lewin SR. Effect of ipilimumab on the HIV reservoir in an HIV-infected individual with metastatic melanoma. Aids. 2015;29:504-6.

19. Heppt MV, Schlaak M, Eigentler TK, Kahler KC, Kiecker F, Loquai C, Meier F, Tomsitz D, Brenner N, Niesert AC, et al. Checkpoint blockade for metastatic melanoma and Merkel cell carcinoma in HIV-positive patients. Ann Oncol. 2017;28:3104-6.

20. Rai R, Ezeoke OM, McQuade JL, Zimmer L, Koo C, Park JJ, Ardolino L, Yip D, Goldinger S, Cohen JV, et al: 1148PDImmunotherapy in patients with concurrent solid organ transplant, HIV, and hepatitis B and C. Ann Oncol 2017, 28:mdx376.013-mdx376.013.

\section{Ready to submit your research? Choose BMC and benefit from:}

- fast, convenient online submission

- thorough peer review by experienced researchers in your field

- rapid publication on acceptance

- support for research data, including large and complex data types

- gold Open Access which fosters wider collaboration and increased citations

- maximum visibility for your research: over $100 \mathrm{M}$ website views per year

At BMC, research is always in progress.

Learn more biomedcentral.com/submissions 